\title{
Characterization of in vivo-acquired resistance to macrolides of Mycoplasma gallisepticum strains isolated from poultry
}

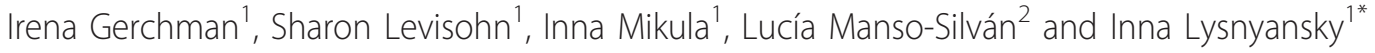

\begin{abstract}
The macrolide class of antibiotics, including tylosin and tilmicosin, is widely used in the veterinary field for prophylaxis and treatment of mycoplasmosis. In vitro susceptibility testing of 50 strains of M. gallisepticum isolated in Israel during the period 1997-2010 revealed that acquired resistance to tylosin as well as to tilmicosin was present in 50\% of them. Moreover, $72 \%$ (13/18) of the strains isolated from clinical samples since 2006 showed acquired resistance to enrofloxacin, tylosin and tilmicosin. Molecular typing of the field isolates, performed by gene-target sequencing (GTS), detected 13 molecular types (I-XIII). Type II was the predominant type prior to 2006 whereas type $X$, first detected in 2008 , is currently prevalent. All ten type $X$ strains were resistant to both fluoroquinolones and macrolides, suggesting selective pressure leading to clonal dissemination of resistance. However, this was not a unique event since resistant strains with other GTS molecular types were also found. Concurrently, the molecular basis for macrolide resistance in $M$. gallisepticum was identified. Our results revealed a clear-cut correlation between single point mutations A2058G or A2059G in domain V of the gene encoding $23 \mathrm{~S}$ rRNA (rrnA, MGA_01) and acquired macrolide resistance in $M$. gallisepticum. Indeed, all isolates with MIC $\geq 0.63 \mu \mathrm{g} /$ $\mathrm{mL}$ to tylosin and with MIC $\geq 1.25 \mu \mathrm{g} / \mathrm{mL}$ to tilmicosin possess one of these mutations, suggesting an essential role in decreased susceptibility of $M$. gallisepticum to 16-membered macrolides.
\end{abstract}

\section{Introduction}

Mycoplasma gallisepticum is the major mycoplasma pathogen in poultry, causing Chronic Respiratory Disease in chickens and Infectious Sinusitis in turkeys [1]. In Israel, due to control measures, M. gallisepticum outbreaks occur infrequently in breeder flocks. However, M. gallisepticum is sometimes present in meat-type turkey flocks or other types of commercial flocks maintained for long growing periods with minimal biosecurity, which thereby may provide reservoirs of infection. Macrolides (tylosin, tilmicosin) and fluoroquinolones (enrofloxacin, difloxacin) are among the antibiotic families most widely used in poultry in many countries [2], including Israel.

Tylosin has been used prophylactically and therapeutically for mycoplasmosis in certain poultry sectors in Israel for more than 40 years [3]. Historically, tylosin

\footnotetext{
* Correspondence: innal@moag.gov.il

${ }^{1}$ Mycoplasma Unit, Division of Avian and Fish Diseases, Kimron Veterinary Institute, Bet Dagan, 50250, Israel

Full list of author information is available at the end of the article
}

was used for eradication of M. gallisepticum by egg-dipping at the same time as being used for control in the progeny, a practice that was linked to the emergence of $M$. gallisepticum tylosin-resistant strains, initially in turkey breeder flocks and later in broilers and meat-type turkeys [3]. With the successful eradication of M. gallisepticum in breeder flocks, there was a marked decrease in the use of tylosin in poultry and, probably as a consequence, only sporadic detection of M. gallisepticum tylosin-resistant strains [4]. Notably, tylosin-resistant $M$. gallisepticum strains, all with the same molecular profile identified by random amplification of polymorphic DNA analysis, were consistently isolated in one geographical region of Israel where tylosin-treated commercial flocks served as an environmental reservoir for outbreaks in breeder flocks [5].

The antibacterial activity of macrolides is due to inhibition of bacterial protein synthesis by binding to the $23 \mathrm{~S}$ rRNA component of the bacterial $50 \mathrm{~S}$ ribosomal subunit. Usually in bacteria with a small number of rRNA operons, such as mycoplasmas, acquired
C Biomed Central

(c) 2011 Gerchman et al; licensee BioMed Central Ltd. This is an Open Access article distributed under the terms of the Creative Commons Attribution License (http://creativecommons.org/licenses/by/2.0), which permits unrestricted use, distribution, and reproduction in any medium, provided the original work is properly cited. 
resistance to macrolides has been associated with mutations within domain II or $\mathrm{V}$ of the $23 \mathrm{~S}$ rRNA genes or in $r p l D$ and $r p l V$, genes encoding ribosomal proteins L4 and L22 [6].

Enrofloxacin has a fairly wide spectrum of efficacy and has been used as the routine choice for treatment of a variety of poultry diseases in addition to mycoplasmosis in many countries [2,7] including Israel where it was first introduced in the early 1990s. This practice may account for the relatively rapid emergence of enrofloxacin-resistance in clinical isolates of $M$. gallisepticum recently reported by our group [8] and others [9]. Molecular characterization of the quinolone resistance-determining regions (QRDRs) of DNA gyrase and topoisomerase IV in M. gallisepticum isolates with different levels of susceptibility to fluoroquinolones showed that enrofloxacin-resistant isolates harbor amino acid substitutions in the QRDRs of each of three proteins (GyrA, GyrB, and ParC) [10].

The present study reports on in vitro susceptibility to two macrolides (tylosin and tilmicosin) and to enrofloxacin in $50 \mathrm{M}$. gallisepticum clinical strains isolated in Israel during 1997-2010. In addition, by sequence analysis of domains II and V of the 23S rRNA genes as well as genes encoding ribosomal proteins L4 and L22 in clinical isolates with different levels of susceptibility to tylosin and tilmicosin, we investigated the mechanism of M. gallisepticum acquired-resistance to these two 16membered macrolides. Furthermore, molecular typing by gene targeted sequencing (GTS) [11] was performed to characterize the $M$. gallisepticum strains isolated in Israel over time, attempting to gain insight into the emergence and dissemination of the resistance phenotype(s) in this population.

\section{Materials and methods}

\section{M. gallisepticum strains and growth conditions}

A total of $50 \mathrm{M}$. gallisepticum strains isolated during the period 1997-2010 from 15 meat-type turkey flocks (MT), 7 turkey breeder flocks (TB), 23 broiler breeder flocks (BB), 4 broiler flocks (B) and 1 Leghorn-type breeder flock (LB) were analyzed (Table 1). These include 24 isolates described previously [10]. In addition, reference strains M. gallisepticum PG31 (ATCC 19610), M. gallisepticum S6 (ATCC 15302), prototype pathogen M. gallisepticum R, and Israeli reference strain 227 were included in this study. Samples from breeder flocks (TB, $\mathrm{BB}$ and $\mathrm{LB}$ ) were submitted to the laboratory within the framework of the national mycoplasma control program; clinical signs were not necessarily present. In contrast, samples from MT and B flocks were received by survey of flocks with respiratory disease and/or serological evidence of $M$. gallisepticum infection. The outbreaks had no known epidemiological link.
All isolates were propagated at $37^{\circ} \mathrm{C}$ in Frey's broth medium. Isolates of $M$. gallisepticum were identified by direct immunofluorescence (IMF) of colonies using species-specific conjugated antiserum. Mixed cultures were cloned to IMF homogeneity by microscopic selection of target colonies. Notably, isolates were not filtered cloned in order to avoid inadvertent selection of a non-representative variant [12]. Aliquots of low-passage (3-4 p) cultures were stored at $-80^{\circ} \mathrm{C}$.

\section{Antimicrobial susceptibility testing}

In vitro susceptibility for tylosin (98\%, batch RS 0315), tilmicosin (91\%, batch RS 0263), kindly provided by Eli Lilly (Indianapolis, IN, USA), and for enrofloxacin (98\% active material, Fluka AG, Seelze, Germany) was determined by the microbroth dilution method as previously described [13], following the guidelines recommended by Hannan [14]. Two-fold dilutions of antibiotics from $0.04-10 \mu \mathrm{g} / \mathrm{mL}$ were tested. For M. gallisepticum strains sensitive to macrolides or to fluoroquinolones at the lowest concentration in the preliminary test, an additional round of testing with tylosin and tilmicosin or enrofloxacin in the range $0.0008-0.2 \mu \mathrm{g} / \mathrm{mL}$ was performed. The microbiological criterion (epidemiological cut-off value) was used for interpretation of MIC results [15].

MIC values for tylosin and tilmicosin in reference strains S6, R and PG31 were $0.0063 \mu \mathrm{g} / \mathrm{mL}$ and 0.0032 $\mu \mathrm{g} / \mathrm{mL}$, respectively for each of the strains (data not shown). The MIC values for enrofloxacin in reference strains S6, R and PG31 were 0.01, 0.005 and 0.01 $\mu \mathrm{g} /$ $\mathrm{mL}$, respectively (data not shown). The MIC values for tylosin, tilmicosin, and enrofloxacin in this study were consistent with the previously published values for these strains [8,16-19].

The MIC values for Israeli reference strain 227 were $1.25 \mu \mathrm{g} / \mathrm{mL}$ for tylosin and tilmicosin and $0.05 \mu \mathrm{g} / \mathrm{mL}$ for enrofloxacin (data not shown).

\section{PCR amplification and sequence analysis of domains II} and $\mathrm{V}$ of the $23 \mathrm{~S}$ rRNA genes, $r p / D$ and $r p / V$ genes

M. gallisepticum genomic DNA was extracted from 10 $\mathrm{mL}$ logarithmic-phase broth cultures using the Maxwell $^{\circledR} 16$ apparatus and Maxwell $16^{\mathrm{TM}}$ Cell DNA Purification Kit (Promega, Madison, USA) according to the manufacturer's instructions. Primers used in this study were designed on the nucleotide sequence of $M$. gallisepticum strain $\mathrm{R}_{\text {low }}$ (AE015450, [20]) (Table 2). Since the nucleotide sequences of the two $M$. gallisepticum 23S rRNA genes (MGAr01 ( $r r n A)$ and MGAr04 ( $r r n B)$ ) are highly homologous, four different PCR systems were designed to specifically amplify domains II and $\mathrm{V}$ in each gene. One of the primers in each PCR system (initial step) recognizes a sequence in the respective 
Table 1 In vitro sensitivity, GTS typing and molecular characterization of domain $V$ in the $23 S$ rRNA genes of $M$. gallisepticum clinical isolates

\begin{tabular}{|c|c|c|c|c|c|c|c|c|c|}
\hline \multirow[t]{2}{*}{ No } & \multirow[t]{2}{*}{ Strain } & \multirow[t]{2}{*}{ Sector $^{a}$} & \multirow[t]{2}{*}{ Year } & \multicolumn{3}{|c|}{ Susceptibility } & \multirow[t]{2}{*}{ GTS type } & \multicolumn{2}{|c|}{ Domain $\mathrm{V}$ sequence $^{\mathrm{b}}$} \\
\hline & & & & Ty & $\mathrm{Tm}$ & En & & $r r n A$ & $r r n B$ \\
\hline & S6 & & & $\mathrm{S}$ & S & S & NA & A2058/A2059 & A2058/A2059 \\
\hline & $\mathrm{R}$ & & & $\mathrm{S}$ & S & S & NA & A2058/A2059 & A2058/A2059 \\
\hline & PG31 & & & $\mathrm{S}$ & S & S & NA & NA & NA \\
\hline & 227 & $\mathrm{~TB}$ & 1978 & $\mathrm{R}$ & R & $S$ & 1 & G2058/- & $-/ G 2059$ \\
\hline 1 & $\mathrm{HZ}-19$ & MT & 1997 & $S$ & S & $S^{*}$ & $\|$ & $-/-$ & -/G2059 \\
\hline 2 & $\mathrm{NMH}-2$ & $\mathrm{~TB}$ & 1997 & $\mathrm{R}$ & R & S & III & $-/ G 2059$ & $-/ G 2059$ \\
\hline 3 & BSY-10 & $\mathrm{B}$ & 1998 & $\mathrm{~S}$ & S & $\mathrm{S}^{*}$ & IV & $-/-$ & $-/ G 2059$ \\
\hline 4 & TY-6 & MT & 1998 & $\mathrm{R}$ & R & $S^{*}$ & IV & -/G2059 & $-/ G 2059$ \\
\hline 5 & DSD-4 & MT & 2000 & $\mathrm{R}$ & R & $S^{*}$ & $\|$ & -/G2059 & $-/ G 2059$ \\
\hline 6 & YS & $\mathrm{BB}$ & 2001 & S & S & $S$ & $\|$ & $-/-$ & $-/ G 2059$ \\
\hline 7 & EK & $\mathrm{BB}$ & 2001 & $\mathrm{~S}$ & S & $S$ & $\|$ & $-/-$ & -/G2059 \\
\hline 8 & KBR-3 & MT & 2002 & $\mathrm{~S}$ & S & $\mathrm{S}^{*}$ & $\|$ & $-/-$ & -/G2059 \\
\hline 9 & KR-11 & MT & 2002 & $\mathrm{R}$ & R & $\mathrm{S}^{*}$ & $\|$ & $-/ G 2059$ & -/G2059 \\
\hline 10 & TMM & $\mathrm{BB}$ & 2002 & $\mathrm{~S}$ & S & S & $\|$ & $-/-$ & $-/ G 2059$ \\
\hline 11 & $\mathrm{KSH}$ & $\mathrm{BB}$ & 2002 & $\mathrm{~S}$ & S & $S$ & $\|$ & $-/-$ & -/G2059 \\
\hline 12 & SMR & $\mathrm{TB}$ & 2002 & $\mathrm{~S}$ & S & $S$ & V & $-/-$ & $-/-$ \\
\hline 13 & $\mathrm{BR}$ & $\mathrm{BB}$ & 2002 & $\mathrm{~S}$ & S & S & $\|$ & $-/-$ & -/G2059 \\
\hline 14 & NLP & $\mathrm{TB}$ & 2002 & $\mathrm{R}$ & $\mathrm{R}$ & $S$ & $\|$ & -/G2059 & -/G2059 \\
\hline 15 & PYN & $\mathrm{BB}$ & 2002 & S & S & $S$ & $\|$ & $-/$ & -/G2059 \\
\hline 16 & SBC & TB & 2002 & $\mathrm{R}$ & R & $S$ & $\|$ & -/G2059 & $-/ G 2059$ \\
\hline 17 & MKK & $\mathrm{BB}$ & 2002 & $\mathrm{~S}$ & S & S & $\|$ & $-/-$ & -/G2059 \\
\hline 18 & NR-3 & $L B$ & 2003 & $\mathrm{R}$ & R & $\mathrm{S}^{*}$ & $\|$ & -/G2059 & -/G2059 \\
\hline 19 & $\mathrm{NH}-7$ & TB & 2003 & $\mathrm{R}$ & $R$ & $\mathrm{~S}^{*}$ & $\|$ & -/G2059 & $-/ G 2059$ \\
\hline 20 & RFG & $\mathrm{TB}$ & 2003 & $\mathrm{~S}$ & S & S & $\|$ & $-/-$ & -/G2059 \\
\hline 21 & TR-9 & MT & 2004 & $\mathrm{R}$ & R & $\mathrm{S}^{*}$ & $\|$ & -/G2059 & -/G2059 \\
\hline 22 & ABA-6 & MT & 2005 & $\mathrm{~S}$ & S & $\mathrm{R}^{*}$ & $\|$ & $-/-$ & -/G2059 \\
\hline 23 & BAK-2 & $\mathrm{BB}$ & 2005 & $\mathrm{~S}$ & S & $S^{*}$ & $\|$ & $-/-$ & $-/-$ \\
\hline 24 & BNC-2 & MT & 2005 & $\mathrm{~S}$ & S & $S^{*}$ & $\mathrm{Vl}$ & $-/-$ & $-/-$ \\
\hline 25 & YDK-3 & MT & 2005 & $\mathrm{~S}$ & S & $\mathrm{R}^{*}$ & $\|$ & $-/-$ & $-/ G 2059$ \\
\hline 26 & MT-13 & B & 2005 & $\mathrm{~S}$ & S & $R^{*}$ & $\|$ & $-/-$ & $-/ G 2059$ \\
\hline 27 & MYZ-8 & $\mathrm{BB}$ & 2005 & $\mathrm{~S}$ & S & $R^{*}$ & VII & $-/-$ & -/G2059 \\
\hline 28 & SYR-3 & $\mathrm{BB}$ & 2005 & S & S & $R^{*}$ & $\|$ & $-/-$ & $-/ G 2059$ \\
\hline 29 & MKT-3 & MT & 2005 & $\mathrm{~S}$ & S & $\mathrm{R}^{*}$ & $\|$ & $-/-$ & $-/ G 2059$ \\
\hline 30 & SM-9 & MT & 2005 & $\mathrm{R}$ & R & $\mathrm{S}^{*}$ & $\|$ & -/G2059 & $-/ G 2059$ \\
\hline 31 & MAR-1 & $\mathrm{B}$ & 2005 & $\mathrm{R}$ & $\mathrm{R}$ & $\mathrm{R}^{*}$ & $\|$ & -/G2059 & -/G2059 \\
\hline 32 & KYN-6 & $\mathrm{BB}$ & 2005 & $\mathrm{R}$ & $\mathrm{R}$ & $\mathrm{S}^{*}$ & $\|$ & -/G2059 & -/G2059 \\
\hline 33 & MSA-9 & $B$ & 2006 & $\mathrm{~S}$ & S & $\mathrm{R}^{*}$ & $\|$ & $-/-$ & -/G2059 \\
\hline 34 & $J \mathrm{~J}-10$ & MT & 2006 & $\mathrm{~S}$ & S & $\mathrm{R}^{*}$ & $\|$ & $-/-$ & -/G2059 \\
\hline 35 & MDE-3 & $\mathrm{BB}$ & 2006 & $\mathrm{R}$ & $\mathrm{R}$ & $R^{*}$ & VIII & -/G2059 & -/G2059 \\
\hline 36 & RV-2 & $\mathrm{BB}$ & 2007 & $\mathrm{~S}$ & $S$ & $\mathrm{~S}^{*}$ & IX & $-/-$ & $-/-$ \\
\hline 37 & BLF-6 & $\mathrm{BB}$ & 2008 & $\mathrm{R}$ & $\mathrm{R}$ & $\mathrm{R}$ & $x$ & -/G2059 & -/G2059 \\
\hline 38 & KFM & $\mathrm{BB}$ & 2009 & $\mathrm{R}$ & R & $\mathrm{R}$ & $x$ & -/G2059 & $-/ G 2059$ \\
\hline 39 & SU & MT & 2009 & $\mathrm{R}$ & R & $\mathrm{R}$ & $X I$ & -/G2059 & -/G2059 \\
\hline 40 & LH-22 & MT & 2009 & $\mathrm{R}$ & R & $\mathrm{R}$ & $x$ & -/G2059 & -/G2059 \\
\hline 41 & VR-8 & $\mathrm{BB}$ & 2009 & $\mathrm{~S}$ & S & $\mathrm{R}$ & XII & $-/$ & $-/$ \\
\hline 42 & KLD-8 & $\mathrm{BB}$ & 2009 & $\mathrm{R}$ & R & $\mathrm{R}$ & $x$ & -/G2059 & $-/ G 2059$ \\
\hline 43 & CK-4 & $\mathrm{BB}$ & 2009 & $\mathrm{R}$ & R & $\mathrm{R}$ & $x$ & -/G2059 & -/G2059 \\
\hline 44 & KC-4 & $\mathrm{BB}$ & 2009 & $\mathrm{R}$ & R & $\mathrm{R}$ & $x$ & -/G2059 & -/G2059 \\
\hline 45 & KTY & $\mathrm{BB}$ & 2009 & $\mathrm{R}$ & $\mathrm{R}$ & $\mathrm{R}$ & VIII & -/G2059 & -/G2059 \\
\hline
\end{tabular}


Table 1 In vitro sensitivity, GTS typing and molecular characterization of domain V in the 23S rRNA genes of $M$. gallisepticum clinical isolates (Continued)

\begin{tabular}{|c|c|c|c|c|c|c|c|c|c|}
\hline 46 & TLS-2 & $\mathrm{BB}$ & 2010 & $S$ & $S$ & $S$ & $X I I I$ & $-1-$ & $-/-$ \\
\hline 47 & MCK & $\mathrm{BB}$ & 2010 & $\mathrm{R}$ & $\mathrm{R}$ & $\mathrm{R}$ & $x$ & -/G2059 & $-/-$ \\
\hline 48 & MAT-394 & $\mathrm{BB}$ & 2010 & $\mathrm{R}$ & $\mathrm{R}$ & $\mathrm{R}$ & $x$ & -/G2059 & $-/ G 2059$ \\
\hline 49 & $M N-2$ & MT & 2010 & $\mathrm{R}$ & $\mathrm{R}$ & $\mathrm{R}$ & $x$ & -/G2059 & $-/ G 2059$ \\
\hline 50 & NLY & $\mathrm{TB}$ & 2010 & $\mathrm{R}$ & $\mathrm{R}$ & $\mathrm{R}$ & $x$ & -/G2059 & $-/ G 2059$ \\
\hline
\end{tabular}

${ }^{\mathrm{a}} \mathrm{B}=$ Broiler; $\mathrm{BB}=$ Broiler breeder; $\mathrm{LB}=$ Leghorn-type breeder; $\mathrm{MT}=$ Meat-type turkey; $\mathrm{TB}=$ turkey breeder.

${ }^{\mathrm{b}}$ Nucleotide present at positions 2058 and 2059.

"-", No polymorphism compared to the sequence of the reference strains.

* MIC values for En published in Gerchman et al. [13] and in Lysnyansky et al. [10].

$\mathrm{NA}=$ not analyzed.

flanking gene (MGA_0754 to amplify domain V and MGA_0746 for domain II of MGAr01; MGA_1046 for domain V and MGAr03 for domain II of MGAr04) (Table 2). The primers MG23S-1F and MG23S-1R (for the nested reactions) contain a nucleotide sequence found in domain V of both MGAr01 and MGAr04 genes. Likewise, primers MG-rRNAII-F and MGrRNAII-R (nested) recognize a nucleotide sequence in domain II of both MGAr01 and MGAr04 genes (Table 2). In addition, gene-specific primers corresponding to genes $r p l D$ and $r p l V$, encoding ribosomal proteins $L 4$ and L22, respectively, were synthesized (Table 2).

PCR reaction mixtures contained $50 \mu \mathrm{L}$ Ready-Mix PCR Master Mix (ABGene, Surrey, UK) with $30 \mathrm{pmol} /$ $\mu \mathrm{L}$ of each primer (Sigma-Aldrich, Rehovot, Israel) and about 100 ng of mycoplasmal DNA. PCR amplifications were carried out in an MJ Research PT200 thermocycler (Waltham MA, USA). PCR conditions for primers MG23S-1F/MG-0754-R and MG-23S-1F/MG-1046-R were the following: one cycle of $3 \mathrm{~min}$ at $95^{\circ} \mathrm{C}, 1 \mathrm{~min} 45 \mathrm{~s}$ at $56^{\circ} \mathrm{C}, 1 \mathrm{~min} 45 \mathrm{~s}$ at $72^{\circ} \mathrm{C} ; 30$ cycles of $95^{\circ} \mathrm{C}$ for $45 \mathrm{~s}, 56^{\circ}$ $\mathrm{C}$ for $45 \mathrm{~s}$, and $72^{\circ} \mathrm{C}$ for $1 \mathrm{~min} 45 \mathrm{~s} ; 72^{\circ} \mathrm{C}$ for $10 \mathrm{~min}$. To amplify domain II of the $23 \mathrm{~S}$ rRNA genes (primers MG-mdh-F/MG-rRNAII-R or MG-16S-F/MG-rRNAII$\mathrm{R})$ the following program was used: one cycle of $3 \mathrm{~min}$ at $95^{\circ} \mathrm{C}, 2 \mathrm{~min}$ at $52^{\circ} \mathrm{C}, 2 \mathrm{~min} 30 \mathrm{~s}$ at $72^{\circ} \mathrm{C} ; 30$ cycles of $95^{\circ} \mathrm{C}$ for $45 \mathrm{~s}, 52^{\circ} \mathrm{C}$ for $45 \mathrm{~s}$, and $72^{\circ} \mathrm{C}$ for $2 \mathrm{~min} ; 72^{\circ} \mathrm{C}$ for $10 \mathrm{~min}$. When the final PCR product of domain II or $\mathrm{V}$ of $23 \mathrm{~S}$ rRNA was absent or was weak on the agarose gel, it was subjected to semi-nested PCR with primers MG-23S-1F/MG-23S-1R (for domain V) or with primers MG-rRNAII-F/MG-rRNAII-R (for domain II) as follows: one cycle of $3 \mathrm{~min}$ at $95^{\circ} \mathrm{C}, 45 \mathrm{~s}$ at $50^{\circ} \mathrm{C}, 1 \mathrm{~min}$ at $72^{\circ} \mathrm{C} ; 30$ cycles of $95^{\circ} \mathrm{C}$ for $30 \mathrm{~s}, 50^{\circ} \mathrm{C}$ for $30 \mathrm{~s}$, and $72^{\circ} \mathrm{C}$ for $1 \mathrm{~min} ; 72^{\circ} \mathrm{C}$ for $10 \mathrm{~min}$. The nested program was also used for amplification of the $r p l D$ (primers MG-L4-F/MG-L4-R) and rplV (primers MG-L22-F/MGL22-R) genes (Table 2). PCR products were visualized on ethidium bromide stained agarose gels, and then purified from the gel using the QIAquick Gel Extraction kit (QIAGEN, Hilden, Germany).
Sequencing was performed at the DNA Sequencing Unit, Weizmann Institute (Rehovot, Israel), utilizing the Applied Biosystems DNA Sequencer with the ABI BigDye Terminator Cycle Sequencing Kit (Applied Biosystems, Foster City, CA, USA). Sequence editing, consensus, and alignment construction were performed using DNASTAR software, version 5.06/5.51, 2003 (Lasergene, Inc. Madison, Wisconsin, USA).

Numbering of the nucleotide substitutions in domain $\mathrm{V}$ of the 23S rRNA sequenced amplicon is according to the sequence of the respective genes in Escherichia coli.

\section{GTS typing}

Molecular typing was performed by modified GTS analysis [11]. The $p v p A, g a p A$, and $l p$ (MGA_0319) partial gene sequences were amplified using primers pvpA 4F/ $3 R$, gapA $3 F / 4 R$, and lp $1 F / 1 R$ described previously [11]. However, the $m g c 2$ gene was amplified using primers $m g c 22 \mathrm{~F} / 2 \mathrm{R}$, previously described by Garcia et al., [21], resulting in an amplicon of about $300 \mathrm{bp}$. Amplified gene fragments of the respective genes were sequenced as described above.

The sequences obtained from each corresponding forward and reverse primer were assembled using the SeqMan program (Lasergene, DNASTAR) and the extremities showing single strand sequences, as well as aberrant sequences, were trimmed. All sequences obtained for each gene were aligned using Clustal V (Megalign, Lasergene, DNASTAR, Madison, Wisconsin, USA) and trimmed to the same size for diversity analysis. Phylogenetic trees for individual genes were constructed from the Clustal V alignments by the neighborjoining method and 1000 bootstrap replicate analysis using the MEGA 5 software [22,23]. In contrast with the previously published GTS analysis, in which $m g c 2$ and $p v p A$ gene fragments were $584 \mathrm{bp}$ and $455 \mathrm{bp}$-long, respectively [11], $m g c 2$ and $p v p A$ sequences were $300 \mathrm{bp}$ and $700 \mathrm{bp}$-long, respectively (sizes corresponding to the M. gallisepticum Rlow genome [20]). The different sequences obtained for each gene fragment were assigned different allele numbers, designated by Arabic 
Table 2 Primers used for PCR amplification and sequencing of domains II and V of 235 rRNAs and ribosomal proteins of L4 and L22 in M. gallisepticum

\begin{tabular}{|c|c|c|c|c|}
\hline Primer designation & $\begin{array}{l}\text { Source of } \\
\text { primer }\end{array}$ & Sequence $\left(5^{\prime}-3^{\prime}\right)$ & Nucleotide position $^{\mathrm{a}}$ & $\begin{array}{l}\text { Amplicon size } \\
\text { (bp) }\end{array}$ \\
\hline \multicolumn{5}{|l|}{ Domain V of MGAr01 } \\
\hline $\begin{array}{l}\text { MG-23S-1F } \\
\text { MG-0754-R }\end{array}$ & $\begin{array}{l}\text { MGAr01 } \\
\text { MGA_0754 }\end{array}$ & $\begin{array}{l}\text { CACAGCTCTATGCTAAATCGC } \\
\text { GATAATTGGTGGAGTTGG }\end{array}$ & $\begin{array}{l}\text { 82312-82332 and } 324019-324039 \\
83691-83708\end{array}$ & 1396 \\
\hline \multicolumn{5}{|c|}{$\begin{array}{l}\text { Nested PCR for domain V of } \\
\text { MGAr01 }\end{array}$} \\
\hline $\begin{array}{l}M G-23 S-1 F^{1} \\
M G-23 S-1 R^{2}\end{array}$ & $\begin{array}{l}\text { MGAr01 } \\
\text { MGAr01 }\end{array}$ & $\begin{array}{l}\text { CACAGCTCTATGCTAAATCGC } \\
\text { GGTCCTCTCGTACTAAG }\end{array}$ & $\begin{array}{l}82312-82332 \text { and } 324019-324039 \\
83175-83191 \text { and 324882- } \\
3244898\end{array}$ & 879 \\
\hline \multicolumn{5}{|l|}{ Domain II of MGAr01 } \\
\hline $\begin{array}{l}\text { MG-mdh-F } \\
\text { MG-rRNAll-R }\end{array}$ & $\begin{array}{l}\text { MGA_0746 } \\
\text { MGAr01 }\end{array}$ & $\begin{array}{l}\text { GCAAGCACGGATGGAAGT } \\
\text { CCACTGTCTGACTGCAAG }\end{array}$ & $\begin{array}{l}79928-79945 \\
81483-81500 \text { and } 323190-323207\end{array}$ & 1572 \\
\hline \multicolumn{5}{|c|}{ Nested PCR fordomain II of MGAr01 } \\
\hline $\begin{array}{l}\text { MG-rRNAII-F } \\
\text { MG-rRNAII-R }\end{array}$ & $\begin{array}{l}\text { MGAr01 } \\
\text { MGAr01 }\end{array}$ & $\begin{array}{l}\text { GGTTTAATACCTAGCAGGAT } \\
\text { CCACTGTCTGACTGCAAG }\end{array}$ & $\begin{array}{l}\text { 80893-80912 and 322600-322619 } \\
81483-81500 \text { and } 323190-323207\end{array}$ & 607 \\
\hline \multicolumn{5}{|l|}{ Domain V of MGAr04 } \\
\hline $\begin{array}{l}\text { MG-23S-1F } \\
\text { MG-1046-R }\end{array}$ & $\begin{array}{l}\text { MGAr04 } \\
\text { MGA_1046 }\end{array}$ & $\begin{array}{l}\text { CACAGCTCTATGCTAAATCGC } \\
\text { GCTAATTGCCTCCTGGTAAC }\end{array}$ & $\begin{array}{l}324019-324039 \text { and } 82312-82332 \\
325669-325688\end{array}$ & 1669 \\
\hline \multicolumn{5}{|c|}{$\begin{array}{l}\text { Nested PCR for domain V of } \\
\text { MGAr04 }\end{array}$} \\
\hline $\begin{array}{l}\text { MG-23S-1F } \\
M G-23 S-1 R^{2}\end{array}$ & $\begin{array}{l}\text { MGAr04 } \\
\text { MGAr04 }\end{array}$ & $\begin{array}{l}\text { CACAGCTCTATGCCTAAATCGC } \\
\text { GGTCCTCTCGTACTAAG }\end{array}$ & $\begin{array}{l}324019-324039 \text { and } 82312-82332 \\
324882-324898 \text { and } 83175-83191\end{array}$ & 879 \\
\hline \multicolumn{5}{|l|}{ Domain II of MGAr04 } \\
\hline $\begin{array}{l}\text { MG-16S-F } \\
\text { MG-rRNAII-R }\end{array}$ & $\begin{array}{l}\text { MGAr03 } \\
\text { MGAr04 }\end{array}$ & $\begin{array}{l}\text { GGAATCACTAGTAATCGC } \\
\text { CCACTGTCTGACTGCAAG }\end{array}$ & $\begin{array}{l}321355-321317 \\
323190-323207 \text { and } 81483-81500\end{array}$ & 1852 \\
\hline \multicolumn{5}{|c|}{$\begin{array}{l}\text { Nested PCR for domain II of } \\
\text { MGAr04 }\end{array}$} \\
\hline $\begin{array}{l}\text { MG-rRNAII-F4 } \\
\text { MG-rRNAII-R }\end{array}$ & $\begin{array}{l}\text { MGAr04 } \\
\text { MGAr04 }\end{array}$ & $\begin{array}{l}\text { GGTTAATACCTAGCAGGAT } \\
\text { CCACTGTCTGACTGCAAG }\end{array}$ & $\begin{array}{l}322600-322619 \text { and } 80893-80912 \\
323190-323207 \text { and } 81483-81500\end{array}$ & 607 \\
\hline \multicolumn{5}{|l|}{$r p / D(L 4)$} \\
\hline $\begin{array}{l}\text { MG-L4-F } \\
\text { MG-L4-R }\end{array}$ & $\begin{array}{l}\text { MGA_0710 } \\
\text { MGA_0710 }\end{array}$ & $\begin{array}{l}\text { CGATTATCTGGAAAAGTTCAAG } \\
\text { GTTCAACCTITCAACTCAGTAT }\end{array}$ & $\begin{array}{l}67500-67522 \\
68084-68106\end{array}$ & 606 \\
\hline \multicolumn{5}{|l|}{$r p / V(\mathrm{~L} 22)$} \\
\hline $\begin{array}{l}\text { MG-L22-F } \\
\text { MG-L22-R }\end{array}$ & $\begin{array}{l}\text { MGA_0716 } \\
\text { MGA_0716 }\end{array}$ & $\begin{array}{l}\text { ATGATCGCAATTGCAAGACAA } \\
\text { CTCCGCTAACTGATTGTITTC }\end{array}$ & $\begin{array}{l}69631-69651 \\
70034-70054\end{array}$ & 423 \\
\hline
\end{tabular}

${ }^{a}$ The primers' positions are based on the complete genome sequence of $M$. gallisepticum strain $\mathrm{R}_{\text {low }}$ (AE015450) [20].

$1,2,3,4$ The primers contain the same nucleotide sequence.

numerals (1, 2, 3, etc; data not shown). The GTS types, based on the allelic profiles of the four genes, were designated by Roman numerals (I, II, III, etc) (Table 1).

The four gene sequences corresponding to each of the GTS types identified amongst the 51 strains analysed, were concatenated head-to-tail for diversity analysis using Darwin 5.0 [24] available at [25]. A distance tree was constructed using the neighbor-joining algorithm with the "simple matching" option (no correction applied to dissimilarities). The "pairwise gap block correction" option was selected with a minimal length for gap blocks of one nucleotide. This implied that all consecutive gaps, starting from one nucleotide, were considered as a single event. A bootstrap analysis with 1000 replicates was performed to test the stability on randomly chosen sets of positions.
Sequences of 50 M. gallisepticum isolates and 1 Israeli reference strain were submitted to GenBank under the following accession numbers: gapA, JN102573-102623; MGA_0319, JN102624-102674; $p v p A$, JN113291-113341; $m g c 2$, JN 13342-113392.

\section{Results}

\section{Antimicrobial susceptibility}

An overview of the MIC values, $\mathrm{MIC}_{50}$, and $\mathrm{MIC}_{90}$ for tylosin, tilmicosin, and enrofloxacin for the 50 strains tested is presented in Table 3. Bimodal distribution of MIC was identified for all three antimicrobial agents, indicating acquired resistance in isolates in the higher range of MIC values.

In Table 1 susceptibility data are presented on an individual strain basis indicating year of isolation and poultry sector of origin. 
Table 3 Distribution of minimal inhibitory concentration (MIC) for tylosin, tilmicosin, and enrofloxacin among 50 M. gallisepticum field strains, determined by the microbroth dilution method

\begin{tabular}{|c|c|c|c|c|c|c|c|c|c|c|c|c|c|c|c|}
\hline \multicolumn{16}{|c|}{ Number of isolates with MIC $(\mu \mathrm{g} / \mathrm{mL})$ of } \\
\hline Antimicrobial agent & $\leq 0.0032$ & 0.0063 & 0.0125 & 0.025 & 0.05 & 0.1 & 0.25 & 0.63 & 1.25 & 2.5 & 5 & $\geq 10$ & $\mathrm{MIC}_{50}$ & $\mathrm{MIC}_{90}$ & $\%$ Resistance \\
\hline Tylosin & 1 & 11 & 10 & 2 & 1 & & & 3 & 8 & 13 & 1 & & 0.05 & 2.5 & 50 \\
\hline Tilmicosin & 16 & 6 & & 2 & & 1 & & & 3 & & 7 & 15 & 0.1 & $\geq 10$ & 50 \\
\hline Enrofloxacin* & & & & 3 & 10 & 9 & 5 & & 2 & 11 & 8 & 2 & 0.25 & 5 & 46 \\
\hline
\end{tabular}

M. gallisepticum strains considered to have acquired resistance according to the microbiological criterion are represented in bold.

* MIC values for enrofloxacin are presented for 26 M. gallisepticum strains tested in this study and for 24 strains tested by the same method with the same reference strains and controls and published previously [6,8].

The molecular basis of macrolide resistance in $M$. gallisepticum clinical isolates

No nucleotide mutations associated with decreased susceptibility to macrolides were identified in the $\operatorname{rlp} D$ and $r l p V$ genes or in domain II of the $23 \mathrm{~S}$ rRNA genes (data not shown). However, sequence analysis of domain $\mathrm{V}$ revealed that all $25 \mathrm{M}$. gallisepticum tylosin and tilmicosin-resistant clinical isolates had nucleotide transitions in one or both $23 \mathrm{~S}$ rRNA genes (Table 1). Twenty-four tylosin and tilmicosin-resistant $M$. gallisepticum strains showed an A2059G transition in both $r r n A$ and $r r n B$ and strain MCK showed an $r r n A$ A2059G transition (Table 1). The Israeli reference strain 227 with MIC of $1.25 \mu \mathrm{g} / \mathrm{mL}$ to tylosin and to tilmicosin had $r r n A$ A2058G and $r r n B$ A2059G transitions. In the cohort of 25 tylosin- and tilmicosin-susceptible clinical isolates, 19 possessed only the $r r n B$ A2059G substitution and 6 did not show any substitution (Table 1). Notably, no increase in the MIC values was found between cohorts of $M$. gallisepticum isolates showing the genotype found in reference strains S6 and R ( $r r n A$ A2058A/A2059A and $r r n B$ A2058A/A2059A) and M. gallisepticum strains possessing the single nucleotide substitution A2059G in $\operatorname{rrnB}$ (Table 1).

\section{Molecular typing of $M$. gallisepticum clinical isolates}

The genetic variability of Israeli $M$. gallisepticum strains was assessed by a modification of the previously described GTS method [11]. Overall, 13 GTS groups, arbitrarily designated I through XIII, were distinguished by analysis of the partial gene sequences of $m g c 2, p v p A$, $g a p A$, and $l p$ (Table 1 and Figure 1). The results show that 38 of the 51 strains analyzed belong to two major groups: GTS type II, comprising 28 isolates, and GTS type X, with ten isolates. Type II was identified in 28/35 (80\%) of M. gallisepticum strains isolated between 1997 and 2006 and was not identified after 2006 (Table 1, No. 1-35). Type X, first detected in 2008, was found in $10 / 14(71 \%)$ of the strains isolated since then (Table 1, No. 37-50). Type X differs from type II by the nucleotide sequences of three genes $(m g c 2, p v p A$, and $l p)$. Two isolates each possess GTS type IV and GTS type VIII. The remaining nine strains were found to have unique patterns. Interestingly, GTS type X is very closely related to type VIII (Figure 1). They diverge only by a single nucleotide polymorphism (SNP) in the $p v p A$ sequence, namely by 1 out of $1837 \mathrm{nt}$ of the concatenated sequences analyzed (0.054\% divergence). GTS type VIII was first identified in 2006 and was found again in 2009.

Notably, the susceptibility profiles of $M$. gallisepticum strains presented in Table 1 show that isolates with molecular type II vary with respect to susceptibility to tylosin and enrofloxacin (11 strains susceptible to both antibiotics, nine resistant to tylosin and susceptible to enrofloxacin, seven susceptible to tylosin and resistant to enrofloxacin, and one resistant to both antibiotics). In contrast, all the M. gallisepticum strains with molecular types VIII and X were resistant to enrofloxacin as well as to tylosin and to tilmicosin (Table 1).

\section{Discussion}

In the present study, the microbiological criterion was used for interpretation of MIC results, since no Clinical and Laboratory Standards Institute breakpoints for tylosin, tilmicosin and enrofloxacin are available for the avian pathogen M. gallisepticum [26]. The bimodal distribution of the cohort of strains tested (Table 3) allows wild-type susceptible populations of bacteria to be distinguished from those with acquired resistance [15,27]. Indeed, according to the data presented in Table 3, $M$. gallisepticum field strains with MIC of $\geq 0.63 \mu \mathrm{g} / \mathrm{mL}$ to tylosin, $\geq 1.25 \mu \mathrm{g} / \mathrm{mL}$ to tilmicosin and $\geq 1.25 \mu \mathrm{g} / \mathrm{mL}$ to enrofloxacin should be considered as resistant strains. The difference between susceptible and resistant populations for macrolides is more than tenfold $(0.05$ vs. $\geq$ 0.63). Using this criterion, $50 \%$ of all M. gallisepticum strains checked in this study were resistant to tylosin and tilmicosin and $46 \%$ were resistant to enrofloxacin (Table 3). Moreover, 12/14 (86\%) and 13/14 (93\%) of recently isolated M. gallisepticum strains (2008-2010) were resistant to tylosin and tilmicosin and to enrofloxacin, respectively (Table 1 ). Resistance to tylosin is not a new phenomena in Israel, being present at least sporadically since the 1970s [3]. Moreover, tylosin-resistant $M$. gallisepticum strains have been previously isolated under field conditions in many countries $[9,19,28-30]$. In 


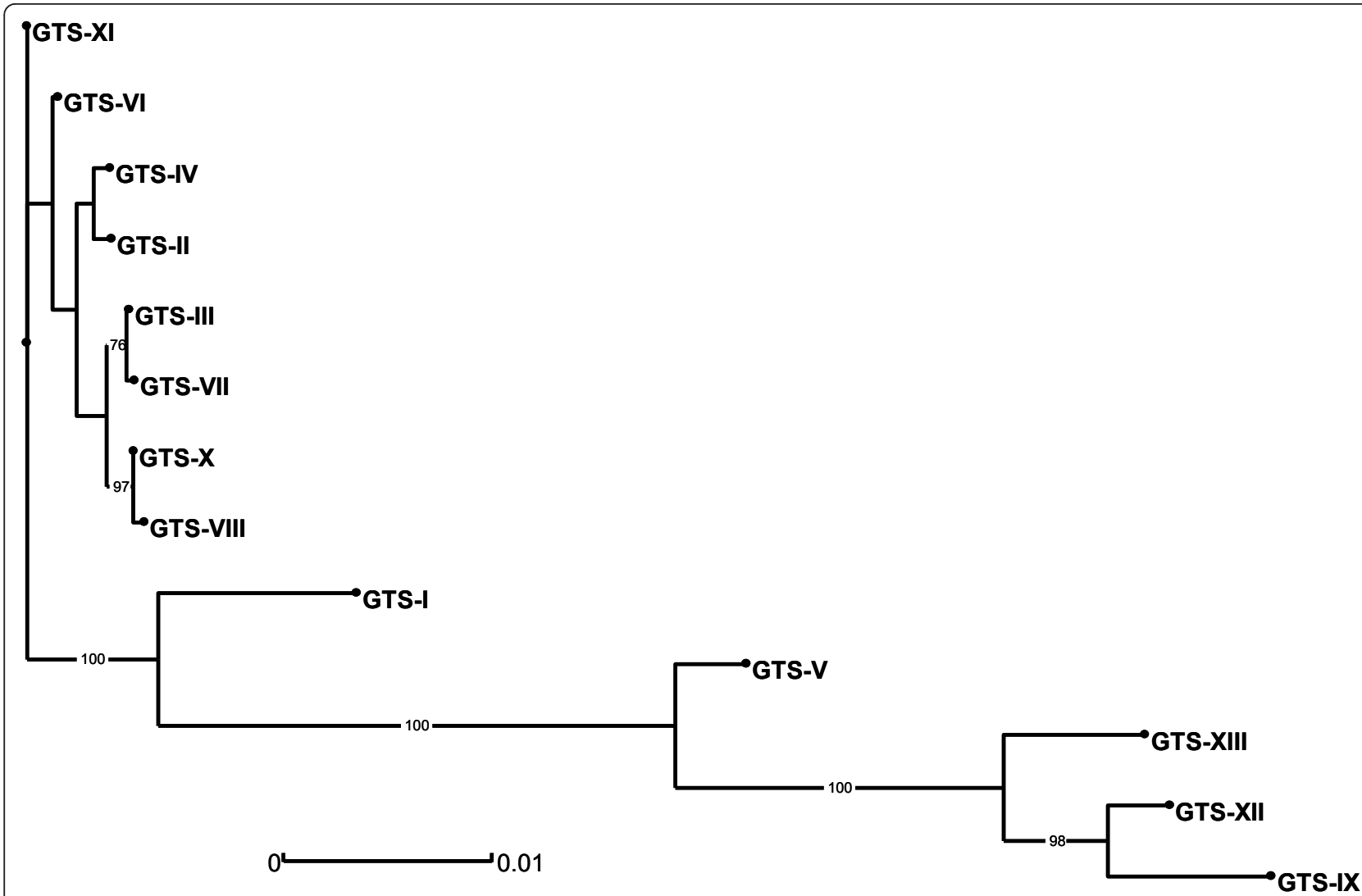

Figure 1 Phylogenetic tree derived from distance analysis of the four concatenated GTS partial gene sequences. The tree was constructed using the neighbor-joining algorithm (Darwin 5.0). A single sequence representing each of the 13 GTS types (I to XIII, Table 1) is displayed. Bootstrap percentage values were calculated from 1000 resamplings and values over $70 \%$ are displayed. The scale bar shows the distance equivalent to 1 substitution per 1000 nucleotide positions.

contrast, although enrofloxacin has been used in local poultry since the early 1990 s, enrofloxacin-resistant $M$. gallisepticum strains were first detected in 2005. However since then, $23 / 29$ (79\%) of the M. gallisepticum field strains tested were resistant to enrofloxacin (Table 1 ). The emergence of widespread resistance to tylosin and tilmicosin in clinical isolates of M. gallisepticum in Israel, often together with resistance to enrofloxacin, may confound treatment of mycoplasma infection in poultry.

The data presented herein demonstrate that a single point mutation in domain $\mathrm{V}$ of the $23 \mathrm{~S}$ rRNA gene of operon $r$ rnA is highly correlated with decreased susceptibility of M. gallisepticum to 16-membered macrolides (Table 1). Indeed, with one exception, all isolates with a MIC of $\geq 0.63 \mu \mathrm{g} / \mathrm{mL}$ to tylosin and a MIC of $\geq 1.25$ $\mu \mathrm{g} / \mathrm{mL}$ to tilmicosin show the transition A2059G in the rrnA. Interestingly, the single exception is $M$. gallisepticum strain 227 that has the nucleotide transition A2058G in domain V of 23S rRNA gene of rrnA (Table 1). This strain was isolated more than 30 years ago and possesses a unique GTS-pattern. No correlation between the presence of nucleotide substitution A2059G in $r r n B$ and acquired resistance or decreased susceptibility to tylosin was found in this study.

It has been shown previously that tylosin-resistant $M$. gallisepticum mutants selected in vitro by erythromycin harbored an A2058G substitution in one of the two 23S rRNA genes [31]. However, since the authors did not use the designation $r r n A$ and $r r n B$, it was not possible to clarify in which 23S rRNA gene the A2058G mutation was identified. In addition, among the tylosin-resistant mutants selected by erythromycin, a G2057A mutation and an A2059G mutation were found in one of the $23 \mathrm{~S}$ rRNA genes. In the same study, in M. gallisepticum tilmicosin-selected tylosin-resistant mutants, two mutations, A2058G and A2503U, occurred in one of the two 23S rRNA genes and those mutants were characterized by markedly high resistance [31]. In another study, in vitro selection of $M$. gallisepticum mutants resistant to tiamulin, a member of the pleuromutilin family of antibiotics that also bind at the peptidyl transfer site in the $23 \mathrm{~S}$ rRNA, resulted in nucleotide substitutions within domain $\mathrm{V}$ of the $23 \mathrm{~S}$ rRNA genes 
[32]. Mutants with the A2058G or the A2059G mutation showed cross-resistance to erythromycin, tilmicosin and tylosin. Interestingly, 1/3 of these mutants harbored A2058G substitution in the $r r n B$ gene, while the other two have A2058G or A2059G in the rrnA gene [32]. The nt substitutions at 2058 or at 2059 have been previously reported as hot spots for macrolide resistance in other bacteria and mycoplasmas [6,33-39].

Molecular typing of the 50 Israeli isolates analyzed in this study revealed the presence of two predominant types: GTS type II dominated until 2006 and type X has been dominant since first detected in 2008. By molecular analysis of the nucleotide sequences of $p v p A, l p$, and $m g c 2$ genes, type $\mathrm{X}$ is relatively distant from type II but very closely related to VIII and may be considered as part of the same clonal complex.

Interestingly, all M. gallisepticum strains of the currently dominant GTS type X (as well as type VIII) are resistant to tylosin, tilmicosin, and enrofloxacin, suggesting clonal dissemination of this phenotype (Table 1). However, this apparently was not a unique occurrence, as evidenced by the presence of a resistant strain with a different GTS pattern (Table 1, No.39).

In conclusion, our study shows the recent emergence of acquired resistance to both the macrolide and fluoroquinolone classes of antibiotics in M. gallisepticum, mainly present in field isolates closely related by molecular typing. A comparison between cohorts of M. gallisepticum tylosin- and tilmicosin-resistant and -susceptible field strains revealed that acquired resistance to tylosin and tilmicosin may be attributed to mutations A2058G or A2059G in domain $\mathrm{V}$ of $23 \mathrm{~S}$ rRNA gene (operon $r r n A$ ). This is the first report of a mechanism for macrolide-resistance in M. gallisepticum clinical isolates. A comparison of MIC in organisms with genetically characterized resistance mutation/s may offer a feasible way to validate MIC breakpoint values. Therefore, the data presented in this paper may help establish a workable breakpoint for macrolides in $M$. gallisepticum. Characterization of domain V of the 23S rRNA genes in a greater number of M. gallisepticum macrolide-resistant clinical isolates, especially those originating from other countries, will help elucidate whether the nt mutations observed in this study are characteristic only of this cohort of strains or are the universal markers for macrolide resistance in this pathogenic mycoplasma.

\section{Acknowledgements}

This research was supported by Research Grant No. 847-0346 from the Israel Egg and Poultry Board.

\section{Author details}

${ }^{1}$ Mycoplasma Unit, Division of Avian and Fish Diseases, Kimron Veterinary Institute, Bet Dagan, 50250, Israel. ${ }^{2}$ CIRAD, UMR CMAEE, F-34398 Montpellier, France.

\section{Authors' contributions}

IG carried out MIC assays, molecular analyses and participated in sequence processing. SL participated in the design of the study, manuscript preparation and its editing. IM participated in molecular analyses and PCR testing. LM-S performed diversity analyses and construction of phylogenetic trees and participated in manuscript preparation. IL designed and coordinated the study and drafted the manuscript. All authors read and approved the final version of the manuscript.

\section{Competing interests}

The authors declare that they have no competing interests.

Received: 15 December 2010 Accepted: 2 August 2011

Published: 2 August 2011

\section{References}

1. Ley DH, Yoder HW: Mycoplasma gallisepticum Infection. In Diseases of Poultry.. 10 edition. Edited by: Calnek BW,Barnes HJ,Beard C,McDougald LR, Saif YM. London: Mosby-Wolfe; 1997:194-207.

2. Hofacre CL: Antimicrobial drug use in poultry. In Antimicrobial Therapy in Veterinary Medicine.. 4 edition. Edited by: Giguere S,Prescott JF,Baggot JD, Walker RD,Dowling PM. Oxford: Wiley Blackwell; 2007:545-553.

3. Levisohn S: Antibiotic sensitivity patterns in field isolates of Mycoplasma gallisepticum as a guide to chemotherapy. Isr J Med Sci 1981, 17:661-666.

4. Levisohn S, Gerchman I: Epidemiology of tylosin-resistant Mycoplasma gallisepticum strains in Israel. American Association of Avian Pathologists 1996; Louisville, Kentucky 1996, 388.

5. Levisohn S, Gerchman I, Berkhoff JE, Ley DH: Molecular tracking of Mycoplasma gallisepticum infection by random amplification of polymorphic DNA. World Veterinary Poultry Association: Aug. 18-22, 1997 1997; Budapest, Hungary 1997, 68

6. Vester B, Douthwaite S: Macrolide resistance conferred by base substitutions in 23S rRNA. Antimicrob Agents Chemother 2001, 45(1):1-12.

7. Gberindyer FA, Wannang N, Akiwuobu CA: Comparative pharmacokinetics/ pharmacodynamic modeling on three brands of $10 \%$ enrofloxacin oral formulations in broiler chickens. Int J Poul Sci 2010, 9(3):273-277.

8. Gerchman I, Lysnyansky I, Perk S, Levisohn S: In vitro susceptibilities to fluoroquinolones in current and archived Mycoplasma gallisepticum and Mycoplasma synoviae isolates from meat-type turkeys. Vet Microbio/ 2008, 131:266-276.

9. Pakpinyo S, Sasipreeyajan J: Molecular characterization and determination of antimicrobial resistance of Mycoplasma gallisepticum isolated from chickens. Vet Microbiol 2007, 125:59-65.

10. Lysnyansky I, Gerchman I, Perk S, Levisohn S: Molecular characterization and typing of enrofloxacin-resistant clinical isolates of Mycoplasma gallisepticum. Avian Dis 2008, 52:685-689.

11. Ferguson NM, Hepp D, Sun S, Ikuta N, Levisohn S, Kleven SH, Garcia M: Use of molecular diversity of Mycoplasma gallisepticum by gene-targeted sequencing (GTS) and random amplified polymorphic DNA (RAPD) analysis for epidemiological studies. Microbiology 2005, 151(6):1883-1893.

12. Rosengarten R, Yogev D: Variant colony surface antigenic phenotypes within mycoplasma strain populations: Implications for species diagnosis and strain standardization. J Clin Microbiol 1996, 34:149-158.

13. Gerchman I, Levisohn S, Mikula I, Lysnyansky I: In vitro antimicrobial susceptibility Mycoplasma bovis isolated in Israel from local and imported cattle. Vet Microbiol 2009, 137:268-275.

14. Hannan PC: Guidelines and recommendations for antimicrobial minimum inhibitory concentration (MIC) testing against veterinary mycoplasma species. Vet Res 2000, 31(4):373-395.

15. Turnidge J, Paterson DL: Setting and revising antibacterial susceptibility breakpoints. Clin Microbiol Rev 2007, 20(3):391-408.

16. Hannan PCT, Windsor GD, de Jong A, Schmeer N, Stegemann H: Comparative susceptibilities of various animal-pathogenic mycoplasmas to fluoroquinolones. Antimicrob Agents Chemother 1997, 41(9):2037-2040.

17. Jordan FTW, Forrester CA, Ripley PH, Burch DG: In vitro and in vivo comparisons of valnemulin, tiamulin, tylosin, enrofloxacin, and lincomycin/spectinomycin against Mycoplasma gallisepticum. Avian Dis 1998, 42(4):738-745.

18. Kempf I, Reeve-Johnson L, Gesbert F, Guittet M: Efficacy of tilmicosin in the control of experimental Mycoplasma gallisepticum infection in chickens. Avian Dis 1997, 41:802-807. 
19. Jordan FTW, Horrocks BK: The minimum inhibitory concentration of Tilmicosin and Tylosin for Mycoplasma gallisepticum and Mycoplasma synoviae and a comparison of their efficacy in the control of Mycoplasma gallisepticum infection in broiler chicks. Avian Dis 1996, 40:326-334.

20. Papazisi L, Gorton TS, Kutish G, Markham PF, Browning GF, Nguyen DK, Swartzell S, Madan A, Mahairas G, Geary SJ: The complete genome sequence of the avian pathogen Mycoplasma gallisepticum strain R(low). Microbiology 2003, 149(Pt 9):2307-2316.

21. Garcia M, Ikuta N, Levisohn S, Kleven SH: Evaluation and comparison of various PCR methods for detection of Mycoplasma gallisepticum infection in chickens. Avian Dis 2005, 49:125-132.

22. Tamura K, Peterson D, Peterson N, Stecher G, Nei M, Kumar S: MEGA5: Molecular evolutionary genetics analysis using maximum likelihood, evolutionary distance, and maximum parsimony methods. Mol Biol Evol 2011, 2011.

23. The Molecular Evolutionary Genetics Analysis (MEGA 5). [http://www. megasoftware.net].

24. Perrier X, Flori A, Bonnot F: Data analysis methods. In Genetic diversity of cultivated tropical plants. Edited by: Hamon P,Seguin M,Perrier X,Glaszmann JC. Enfield: Science Publishers; 2003:43-76.

25. The Dissimilarity Analysis and Representation for Windows. [http:// darwin.cirad.fr/darwin/]

26. Watts JL, Shryock TR, Apley M, Bade DJ, Brown SD, Gray JT, Heine H, Hunter RP, Mevius DJ, Papich MG, Silley P, Zurenko GE: Performance standards for antimicrobial disk and dilution susceptibility tests for bacteria isolated from animals; Approved standard-third edition (M31A3). CLSI 2008, 28(8)

27. Dung TT, Haesebrouck F, Tuan NA, Sorgeloos P, Baele M, Decostere A: Antimicrobial susceptibility pattern of Edwardsiella ictaluri isolates from natural outbreaks of bacillary necrosis of Pangasianodon hypophthalmus in Vietnam. Microb Drug Resist 2008, 14(4):311-316.

28. Kuniyasu C, Yoshida Y, Takano M: Spiramycin- and tylosin-resistant strains of Mycoplasma gallisepticum isolated from breeding chickens and pipped eggs. Natl Inst Anim Health Q 1974, 14:48-53.

29. Hinz KH: In vitro susceptibility of Mycoplasma gallisepticum field strains to tiamulin and tylosin. Deutsche Tierarztliche Wochenschrift 1980, 87:220-223, (in German).

30. Bradbury JM, Yavari CA, Giles CJ: In vitro evaluation of various antimicrobials against Mycoplasma gallisepticum and Mycoplasma synoviae by the micro-broth method, and comparison with a commercially-prepared test system. Avian Pathol 1994, 23:105-115.

31. Wu CM, Wu H, Ning Y, Wang J, Du X, Shen J: Induction of macrolide resistance in Mycoplasma gallisepticum in vitro and its resistance-related mutations within domain V of $23 \mathrm{~S}$ rRNA. FEMS Microbiol Lett 2005, 247(2):199-205.

32. Li BB, Shen JZ, Cao XY, Wang Y, Dai L, Huang SY, Wu CM: Mutations in $23 \mathrm{~S}$ rRNA gene associated with decreased susceptibility to tiamulin and valnemulin in Mycoplasma gallisepticum. FEMS Microbiol Lett 2010, 308:144-149.

33. Pereyre S, Gonzalez P, De Barbeyrac B, Darnige A, Renaudin H, Charron A, Raherison S, Bebear C, Bebear CM: Mutations in 23S rRNA account for intrinsic resistance to macrolides in Mycoplasma hominis and Mycoplasma fermentans and for acquired resistance to macrolides in $M$. hominis. Antimicrob Agents Chemother 2002, 46(10):3142-3150.

34. Pereyre S, Charron A, Renaudin H, Bebear C, Bebear CM: First report of macrolide resistant strains and description of a novel nucleotide sequence variation in the P1 adhesin gene in Mycoplasma pneumoniae clinical strains isolated in France over 12 years. J Clin Microbiol 2007, 45(11):3534-3539.

35. Kobayashi H, Nakajima H, Shimizu Y, Eguchi M, Hata E, Yamamoto K: Macrolides and lincomycin susceptibility of Mycoplasma hyorhinis and variable mutation of domain II and V in 23S ribosomal RNA. J Vet Med Sci 2005, 67(8):795-800.

36. Morozumi M, Hasegawa K, Kobayashi R, Inoue N, Iwata S, Kuroki H, Kawamura N, Nakayama E, Tajima T, Shimizu K, Ubukata K: Emergence of macrolide-resistant Mycoplasma pneumoniae with a 23S rRNA gene mutation. Antimicrob Agents Chemother 2005, 49(6):2302-2306.

37. Lucier TS, Heitzman K, Liu S, Hu PC: Transition mutants in the $23 \mathrm{~S}$ rRNA of erthromycin-resistant mutants of Mycoplasma pneumoniae. Antimicrob Agents Chemother 1995, 39:2770-2773.
38. Matsuoka M, Narita M, Okazaki N, Ohya H, Yamazaki T, Ouchi K, Suzuki I, Andoh T, Kenri T, Sasaki Y, et al: Characterization and molecular analysis of macrolide-resistant Mycoplasma pneumoniae clinical isolates obtained in Japan. Antimicrob Agents Chemother 2004, 48(12):4624-4630.

39. Stakenborg T, Vicca J, Butaye P, Maes D, Minion FC, Peeters J, De Kruif A, Haesebrouck F: Characterization of in vivo acquired resistance of Mycoplasma hyopneumoniae to macrolides and lincosamides. Microb Drug Resist 2005, 11(3):290-294.

doi:10.1186/1297-9716-42-90

Cite this article as: Gerchman et al:: Characterization of in vivo-acquired resistance to macrolides of Mycoplasma gallisepticum strains isolated from poultry. Veterinary Research 2011 42:90.

\section{Submit your next manuscript to BioMed Central and take full advantage of:}

- Convenient online submission

- Thorough peer review

- No space constraints or color figure charges

- Immediate publication on acceptance

- Inclusion in PubMed, CAS, Scopus and Google Scholar

- Research which is freely available for redistribution

Submit your manuscript at www.biomedcentral.com/submit
Biomed Central 